\title{
Palaeobotanical record of the Eemian Interglacial succession at the Jagodne site (Garwolin Plain, central Poland)
}

\author{
Aleksandra BOBER ${ }^{1}$, Dorota BRZOZOWICZ², Danuta DRZYMULSKA ${ }^{3}$, Marcin ŻARSKI ${ }^{4}$ \\ and Magdalena SUCHORA ${ }^{1, *}$ \\ 1 Maria Curie-Skłodowska University, Institute of Earth and Environmental Sciences, al. Kraśnicka 2d, 20-718 Lublin, Poland \\ 2 University of Łódź, Faculty of Geographical Sciences, Narutowicza 88, 90-139 Łódź, Poland \\ 3 University of Białystok, Faculty of Biology, Ciołkowskiego 1J, 15-245 Białystok, Poland \\ 4 Polish Geological Institute - National Research Institute, Rakowiecka 4, 00-975 Warszawa, Poland
}

Bober, A., Brzozowicz, D., Drzymulska, D., Żarski, M., Suchora, M., 2021. Palaeobotanical record of the Eemian Interglacial succession at the Jagodne site (Garwolin Plain, central Poland). Geological Quarterly, 65: 34, doi: 10.7306/gq.1602

Associate Editor: Wojciech Granoszewski

\begin{abstract}
Our high-resolution data of pollen and macrofossils from 2 cores taken from the Jagodne site (Garwolin Plain) reveals a pollen succession covering the final part of the Late Saalian (Marine Isotope Stage MIS 6) and embracing the Eemian (MIS 5e). The results correspond to Regional Pollen Assemblage Zones (RPAZ). The hornbeam phase (E5 RPAZ) has been subdivided into subzones and compared to the corresponding division of the key profile of the Garwolin Plain, Kozłów K2-19. The comparison revealed a considerable sedimentary hiatus in the E5 RPAZ at Jagodne. This is attributed to significant palaeohydrological changes occurring widely in this zone, and also seen at other Eemian sites in Poland. Another specific feature of the Jagodne site is the early, rapid terrestrialisation of the palaeolake and its transformation into a raised bog, which occurred already at the end of the hornbeam phase. The Sphagnum dominated peatbog developed for a long time as evidenced by a thick peat layer covering also the Early Vistulian. Both pollen and plant macrofossil data correspond well to observed lithological boundaries, providing a consistent record of palaeoenvironmental and palaeoclimate changes. The results obtained contribute to knowledge of palaeoenvironmental changes and palaeoclimate interpretation of that area.
\end{abstract}

Key words: Eemian Interglacial, MIS-5e, Garwolin Plain, central Poland, palynology, plant macrofossils.

\section{INTRODUCTION}

Central Poland is an important area for the recognition of palaeoenvironmental changes during the last interglacial, that is correlated with MIS 5e (Marks et al., 2016; Cohen and Gibbard, 2019). In recent years, abundant palynological data from Eemian palaeolakes in Poland, including the high-resolution data of Granoszewski (2003) and Kupryjanowicz (2008), have enabled detailing the Eemian palynostratigraphy (Kupryjanowicz and Granoszewski, 2018) outlined for the territory of Poland by Mamakowa (1989). Furthermore, the combined data from 187 Eemian palynological profiles have served as the basis for plotting isopollen maps of this interglacial (Kupryjanowicz et al., 2018). These have allowed inferences to be made on the directions of migration of forest-forming trees from their glacial

\footnotetext{
* Corresponding author, e-mail: magdalena.suchora@umcs.pl
} Received: March 2, 2021; accepted: May 18, 2021; first published online: July 7,2021 refuges, as well as recognising differences in these with respect to the Holocene.

The new, detailed palynostratigraphy of the Eemian Interglacial enables the detection of low-rank climatic oscillations within this period, and allows conclusions to be drawn about the completeness of individual interglacial phases and, indirectly, also on their duration, despite the lack of absolute dating.

The Garwolin Plain is an area where palaeobotanical investigations have been conducted intensively since the discovery of over 20 Eemian palaeolakes by Żarski, in 2016, during work for the Garwolin sheet of the Detailed Geological Map of Poland (1:50,000; Żarski, 2020). The Garwolin Plain was shaped after the Saalian Glaciation (MIS 6). Within its surficial deposits tills, glacifluvial sands and gravels, as well as eluvial aeolian sands, predominate. During deglaciation of this area, the melting of dead-ice blocks resulted in the formation of multiple lakes that had existed from the end of the Saalian glaciation, through the Eemian Interglacial (MIS 5e) and, locally, into the Early Vistulian (MIS 5a-5d).

In this study, we provide data from two profiles (Ja-0 and Ja-19) drawn from the Jagodne site, which lies within the southern edge of this Eemian palaeolakeland (Żarski, 2020). It is one of the Eemian sites of the Garwolin Plain where a significant 
thickness of interglacial organogenic sediments accumulated as gyttjas and peats, making this newly obtained data a valuable addition to the palynologically documented Eemian sites that have been studied so far. Such sites are located south of the Garwolin Plain, close to the Vistula River valley, namely: Kletnia Stara near Dęblin (Żarski, 1989); Kontrowers near Żelechów (Kupryjanowicz et al., 2003); and Wola Okrzejska near Okrzeja (Żarski et al., 2005). Although the Eemian lakeland in central Poland has been studied for $\sim 20$ years (e.g., Krupiński and Morawski, 1993; Krupiński and Kucharska, 2001; Żarski et al., 2005, 2018; Bruj and Roman, 2007; Roman, 2016; Bober et al., 2018; Pidek et al., 2021; Zalat et al., 2021), a number of problems related to palaeoclimatic and palaeohydrological changes during MIS $5 \mathrm{e}$ in this region, as well as in Poland, remain unresolved. Recently, some questions (e.g. the origin and evolution of Eemian palaeolakes, sedimentary hiatuses, palaeohydrological changes) were discussed by Roman et al. (2021) on the basis of five key sites: Ruszkówek (Mirosław-Grabowska et al., 2009); Kaliska (MirosławGrabowska and Niska, 2007); Kubłowo (Roman and Balwierz, 2010; Mirosław-Grabowska et al., 2018); Besiekierz (Janczyk-Kopikowa, 1991; Mirosław-Grabowska and Niska, 2005); and Parchliny 2014 (Wachecka-Kotkowska et al., 2018).

The preliminary pollen investigation of the Ja-0 core revealed its Eemian age, as the record of the Local Pollen Assemblage Zones (LPAZs) clearly resembled those of the Regional Assemblage Zones (RPAZs) developed by Mamakowa (1989). Disturbances in the pollen curves (Carpinus and Picea) triggered further investigation of this site by palaeobotanical methods.

In this work, we report the results of high-resolution palaeobotanical analysis (palynology and plant macrofossils) from this site, together with its palaeolimnological and palaeoclimate implications.

\section{STUDY SITE}

The Jagodne site $\left(51^{\circ} 56^{\prime} 01^{\prime \prime} \mathrm{N}, 21^{\circ} 37^{\prime} 46^{\prime} \mathrm{E}\right)$ is located on the Garwolin Plain (Fig. 1A), $\sim 0.5 \mathrm{~km}$ north of the villages of Jagodne and Nowy Puznów, and $1 \mathrm{~km}$ to the south-west of Żabieniec village. The site lies within the valley of a small, regulated, unnamed watercourse (Fig. 2B), a right-bank tributary of the Wilga River, which flows into the Vistula River west of the study area. This little valley cuts a post-glacial plateau, the surface of which is built of Saalian tills that are locally overlain by eluvial and aeolian sands (Fig. 2). A numerical elevation model (Fig. 1B) reveals clearly defined valleys that were formed after the Saalian ice sheet retreat (MIS 6). The upper part of the valley where the Jagodne site is located contained a dead ice block at this time. After its melting, an elongated lake was formed (Fig. 3B) that existed through the Eemian Interglacial. Within the Jagodne site the maximum thickness of organogenic deposits reaches $5.30 \mathrm{~m}$.

\section{MATERIAL AND METHODS}

\section{CORING AND LITHOLOGICAL INVESTIGATIONS}

The survey profile Ja- 0 , which was used for preliminary palynological analysis, was sampled by means of a Geoprobe drilling system. The total length of the Ja-0 core was $9.50 \mathrm{~m}$.
Pollen analysis (38 samples) revealed Eemian deposits including gyttjas (depths $5.50-6.80 \mathrm{~m}$ ) overlain by peat. The upper boundary of the interglacial deposits is, however, not well defined. Most probably the transition between the Eemian Interglacial and the Early Vistulian is at depth $\sim 4.45 \mathrm{~m}$. The peat layer in its upper part (above $3.90 \mathrm{~m}$ depth) is interbedded with fine-grained sand (Table 1).

In 2019, the core of Ja-19 was collected for high-resolution studies based on the preliminary diagnosis of the Eemian deposits in the Ja-0 profile (Table 2). The new core was sampled via a Powerprobe drilling system and is located in the direct vicinity of Ja-0 (Fig. 1B).

The newly obtained Ja-19 profile, despite its greater length (9.60 $\mathrm{m}$ in total), greatly resembled that of Ja-0. The organogenic (gyttja and peat) succession, of total length $6.10 \mathrm{~m}$, is present in Ja-19 from 1.70 to $7.80 \mathrm{~m}$ depth (Fig. 3A).

\section{POLLEN ANALYSIS}

From the Ja-0 core, material for palynological research was collected and analysed at regular $5 \mathrm{~cm}$ intervals. The intention was to generate a preliminary recognition of the organogenic succession (Fig. 4). In the closely studied Ja-19 core, the resolution of pollen analysis was $1-5 \mathrm{~cm}$ (101 samples in total, Fig. 5).

Laboratory processing of the samples for pollen analysis followed the standard procedure (Berglund and RalskaJasiewiczowa, 1986). After decalcification in $10 \% \mathrm{HCl}$ and boiling in $3.5 \% \mathrm{KOH}$, the mineral fraction was removed by $40 \%$ hydrofluoric acid (for 24 hours). The samples were then macerated by Erdtman acetolysis. Pollen spectra were calculated from at least two slides until 700-1000 pollen grains had been counted. The total amount of pollen of trees and shrubs (AP) and dwarf shrubs and herbaceous terrestrial plants (NAP) was taken as $100 \%$. The percentage shares of pollen of aquatic plants, spores, redeposited sporomorphs, and colonies of algae of the genera Pediastrum, Botryococcus and Tetraedron were calculated according to the basic sum $(A P+N A P=100 \%)$, but with the given taxon added before calculating its percentages.

The results of palynological analyses are shown in Table 3 and the pollen diagrams (Figs. 4 and 5) were plotted using POLPAL software (Nalepka and Walanus, 2003) and divided into Local Pollen Assemblage Zones (LPAZs), which were assigned to Regional Pollen Assemblage Zones (RPAZs acc. to Mamakowa, 1989).

\section{PLANT MACROFOSSIL ANALYSIS}

Plant macrofossil analysis was performed for the Ja-19 profile for the section between 5.10 and $6.80 \mathrm{~m}$, at a resolution of $2 \mathrm{~cm}$. In the first stage of sample preparation, the deposit was flooded with distilled water with the addition of $10 \% \mathrm{KOH}$. Subsequently, samples were boiled and sieved on a $0.2 \mathrm{~mm}$ mesh. Each sample was analysed for vegetative plant remains (roots, epiderm, periderm, rhizoderm, leaves, stems, and wood) using a Leica DM 3000 light microscope with 200-400x magnification. These were identified with reference to GrosseBrauckmann (1972,1974), Grosse-Brauckmann and Streitz (1992), Mauquoy and van Geel (2007) and the collection of macroscopic plant remains at the Institute of Biology, University of Białystok. In the peat samples the botanical composition was estimated based on the percentage proportion of each taxon tissue in total tissue mass. Where the samples contained mini- 

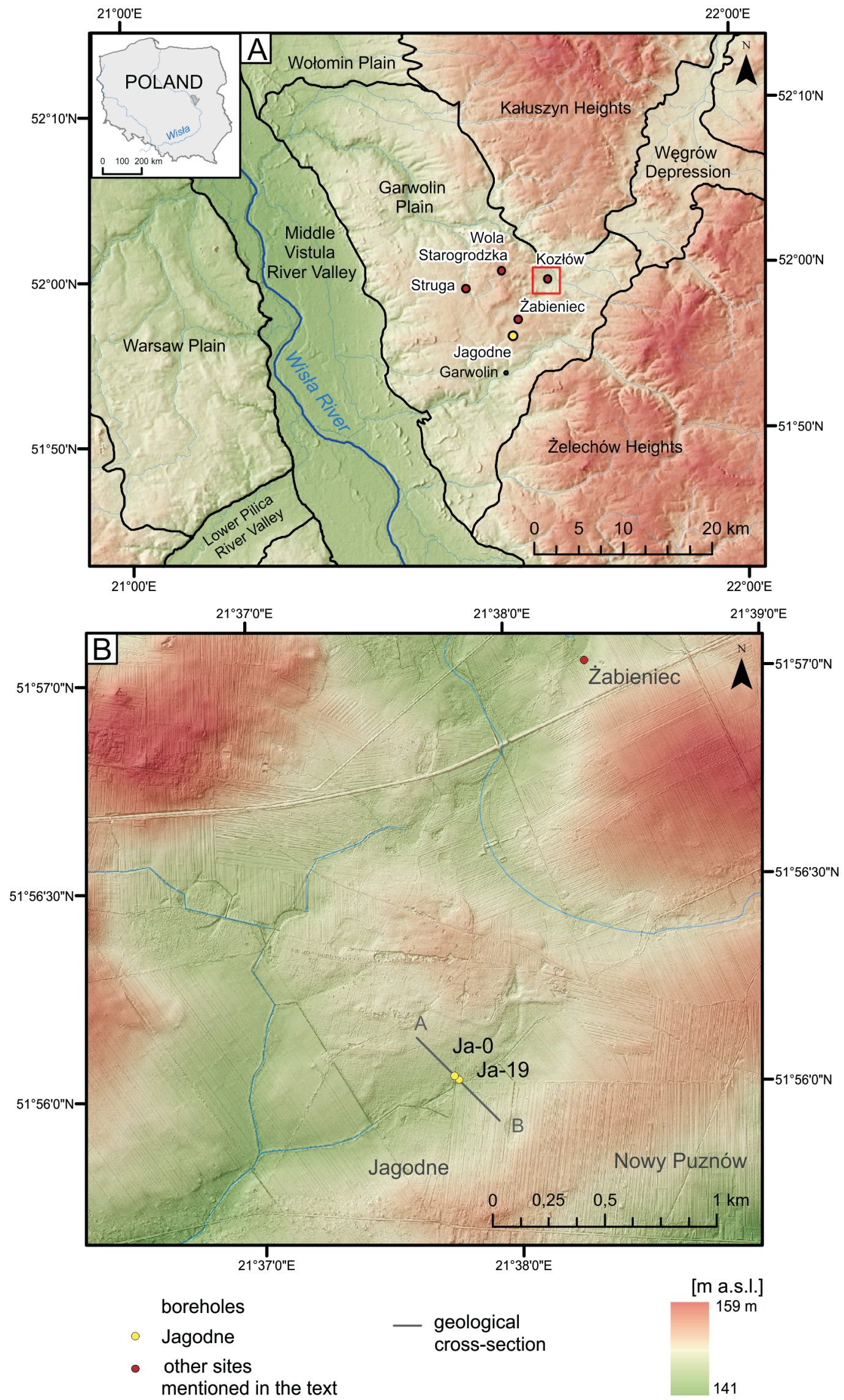

Fig. 1A - location of the Jagodne and other Eemian sites mentioned in the text on the Garwolin Plain (regional division according to Solon et al., 2018); B - detailed location of the Ja-0 and Ja-19 profiles and geological cross-section (see Figs. 2 and 3 ) 


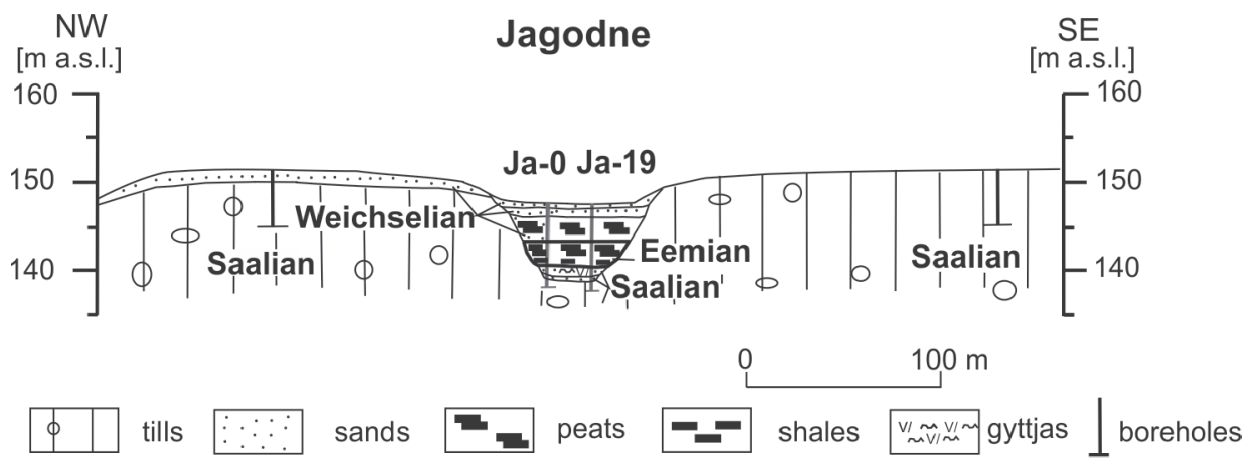

Fig. 2. Geological cross-section of the Jagodne site with boreholes Ja-0 and Ja-19
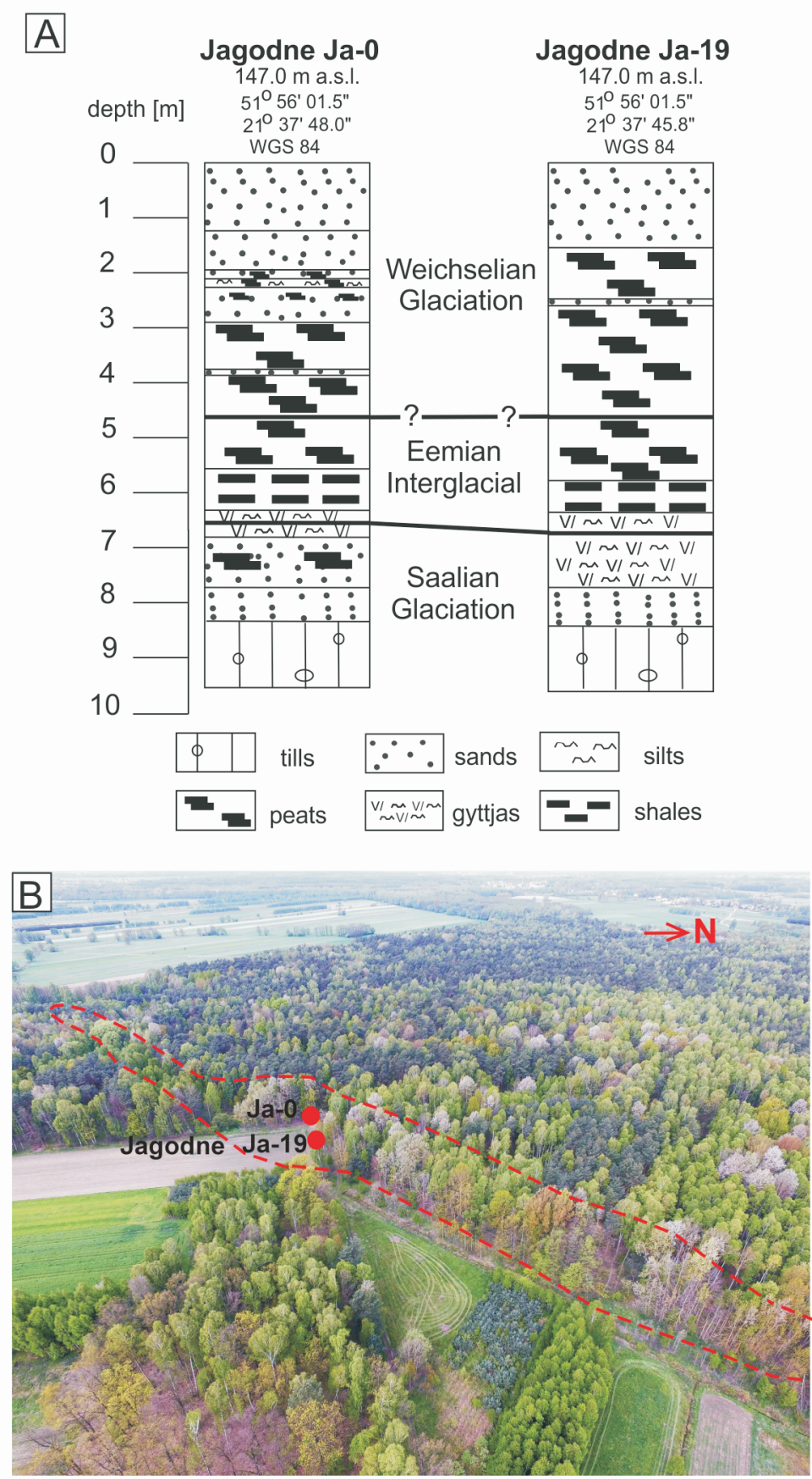

mal amounts of plant tissues, only their presence in the sample was marked.

\section{RESULTS}

\section{CORING AND LITHOLOGICAL DESCRIPTION}

In the Ja- 0 core, a limnic sedimentary succession was encountered between 5.50 and $6.80 \mathrm{~m}$ depth, while the $6.80-8.30 \mathrm{~m}$ depth range consist of fine-grained sands, and the 8.30-9.50 m interval includes glaciolacustrine muds and boulder clay of the Saalian Glaciation. The interglacial gyttjas are very dry in the upper part (between 5.50 and $6.26 \mathrm{~m}$ ) and form shales. These are overlain by peats, which, in their upper part, contain sand intercalations. This entire succession is overlain by poorly sorted sands with an admixture of fine gravel (up to $1 \mathrm{~cm}$ across) between 1.35 and $1.40 \mathrm{~m}$ (Table 1).

In the Ja-19 core, the limnic succession begins with non-calcareous gyttja at depths of 6.55-7.80 m. The underlying deposits consist of fine-grained and poorly sorted sands between 7.80 and $8.20 \mathrm{~m}$ and boulder clays between $8.20-9.60 \mathrm{~m}$. The upper layer of gyttja forms shales (between 5.75 and $6.55 \mathrm{~m}$ depth), overlain by peats up to the depth of $1.70 \mathrm{~m}$. The whole succession is topped with sands. In the section between $0.10-0.39 \mathrm{~m}$, poorly sorted sands include silt and gravel admixtures (Table 2).

\section{POLLEN ANALYSIS}

High-resolution palynological analysis of the Ja-19 profile enabled delimitation of 15 Local Pollen Assemblage Zones (LPAZs), which were assigned to the Regional Pollen Assemblage Zones (RPAZs) determined by Mamakowa (1989).

Table 3 and the pollen diagram of profile Ja-19 (Fig. 5) show that the palaeolake inception in Jagodne started at the transition between the Late Saalian and Eemian Interglacial. Ja-19 LPAZ 1 is characterized by high Pinus sylvestris t. pollen values, as well as a sub-

Fig. 3A - lithostratigraphic profiles of the Ja-0 and Ja-19 cores; $B$ - aerial photo indicating the extent of the Jagodne palaeolake (red dashed line) 
Lithological description of the Ja-0 core

\begin{tabular}{|c|c|}
\hline Depth $[\mathrm{m}]$ & Lithology \\
\hline $0.00-1.20$ & fine- and medium-grained, grey-brown sands \\
\hline $1.20-1.95$ & poorly sorted, brown-grey sands with gravels \\
\hline $1.95-2.05$ & black humic sands \\
\hline $2.05-2.10$ & $\begin{array}{c}\text { fine-grained dark-grey sands with peaty silt } \\
\text { intercalations }\end{array}$ \\
\hline $2.10-2.20$ & black peaty silts \\
\hline $2.20-2.30$ & $\begin{array}{l}\text { fine-grained grey sands with humus } \\
\text { intercalations }\end{array}$ \\
\hline $2.30-2.87$ & fine-grained grey-brown sands \\
\hline $2.87-3.03$ & black peaty silts \\
\hline $3.03-3.50$ & black peat, well decomposed \\
\hline $3.50-3.52$ & fine-grained grey-brown sands \\
\hline $3.52-3.82$ & black peat, well decomposed \\
\hline $3.82-3.90$ & fine-grained, grey sands with black peat laminae \\
\hline $3.90-5.50$ & poorly decomposed, black peats \\
\hline $5.50-6.26$ & black peaty shales \\
\hline $6.26-6.80$ & black peaty gyttjas \\
\hline $6.80-7.55$ & fine-grained sands, light-grey \\
\hline $7.55-7.65$ & $\begin{array}{c}\text { fine-grained, grey sands with humus and peat } \\
\text { laminae }\end{array}$ \\
\hline $7.65-8.30$ & fine-grained grey sands \\
\hline $8.30-9.50$ & grey till below stratified silts \\
\hline
\end{tabular}

stantial share of Betula and high NAP percentages. The NAP spectrum is dominated by Cyperaceae, Artemisia, and Chenopodiaceae. The pollen spectra suggest the presence of open birch-pine forests with the occurrence of Picea and patches of open communities of steppe-tundra type. The Pinus sylvestris t. values are probably partially related to the long-distance transport of pollen. The open character of the forest is also suggested by the presence of Juniperus and Salix pollen. Moreover, the occurrence of Tetraedron, Pediastrum, and Botryococcus testifies to the shallow character of the Jagodne waterbody at that time.

Further samples from Ja-19 LPAZs 2-3 show expansion of Betula, reflecting the development of boreal forests, initially birch and then pine-birch communities. Simultaneously, the continuous presence of Ulmus and Quercus pollen in Ja-19 LPAZs 4-5 points to the beginning of the development of riverine forests as a result of progressive warming. Granoszewski (2003) is of opinion that, together with Ulmus, Quercus robur, a tree with preferences towards wet habitats, was probably part of the developing riparian forests.

Very high percentages of Quercus pollen in the Ja-19 LPAZ 6 (represented here probably by two species of oak) suggest further expansion of oaks within the different forest habitats. With Pinus, they could have formed mixed pine-oak communities, whereas with Ulmus, they could have developed riparian forests. It is also probable that oak with hazel, ash and lime could have formed mixed deciduous forests. The high pollen values of Quercus are accompanied by Hedera helix and
Lithological description of the Ja-19 core

\begin{tabular}{|c|c|}
\hline Depth [m] & Lithology \\
\hline $0.00-1.65$ & $\begin{array}{c}\text { fine- and medium-grained, grey-brown sands } \\
\text { with gravels at top and base }\end{array}$ \\
\hline $1.65-1.70$ & black humic sands \\
\hline $1.70-2.41$ & well decomposed brown-black peats \\
\hline $2.41-2.47$ & fine-grained, humic, dark-grey sands \\
\hline $2.47-4.25$ & black peat, well decomposed \\
\hline $4.25-4.30$ & brown-black peat, poorly decomposed \\
\hline $4.30-4.35$ & sandy, brown-black peat \\
\hline $4.35-4.80$ & brown-black peat, poorly decomposed \\
\hline $4.80-5.00$ & brown-black peat, well decomposed \\
\hline $5.00-5.19$ & black peat, poorly decomposed \\
\hline $5.19-5.29$ & wood insertion \\
\hline $5.29-5.75$ & black peat, poorly decomposed \\
\hline $5.75-6.55$ & grey-black peaty shales \\
\hline $6.65-7.80$ & olive-dark-grey gyttjas \\
\hline $7.80-8.05$ & fine-grained, dark-grey sands with humus \\
\hline $8.05-8.40$ & fine- and medium-grained dark-grey sands \\
\hline $8.40-9.60$ & grey till \\
\hline
\end{tabular}

Viscum - indicators of a warm and humid climate. Moreover, the continuous curves of Fraxinus and Alnus, and the sharply increasing percentage curve of Corylus, as well as numerous Filicales monolete and Musci spores confirm the presence of wet habitats with mosses and ferns close to the lake's shores.

In Ja-19 LPAZs 6-7, the share of Corylus rises considerably and reaches its culmination in the following zone (Ja-19 LPAZ 8). Its sharp increase is accompanied by a rapid decrease of the Betula pollen curve. Most probably, hazel gained dominance in the different habitats surrounding the lake at this time. Granoszewski (2003) suggested that hazel not only formed an oak forest admixture with lime and ash but also developed warm hazel thickets of the type of the modern Peucedano cervariae-Coryletum association (Matuszkiewicz, 2001). The significantly increasing values of Alnus pollen suggest the expansion of alder forest in humid habitat areas, where it could have formed alder-ash riparian forests, and sometimes also alder carrs. Pollen grains of Taxus, a tree associated with a warm, oceanic climate, also occur in this zone. Furthermore, the appearance of yew, together with high shares of alder, strongly points to an increasingly humid climate. An increase in the percentages of Tilia that accompanies the decrease in the share of Quercus in this zone, as well as the beginning of the continuous pollen curve of Carpinus hint at the transformation of mixed deciduous forests into forests dominated by lime and hornbeam. At the same time, NAP reaches minimum values, which suggests that all the available habitats were occupied by forest communities of various types.

Ja-19 LPAZ 9 is dominated by Carpinus (with $52.5 \%$ culmination). This is accompanied by a decrease in Corylus values. Such a change suggests further development of mixed deciduous forests dominated by hornbeam, with lime and a slight admixture of other trees. This community may have resembled the modern Tilio-Carpinetum association (cf. Matuszkiewicz, 


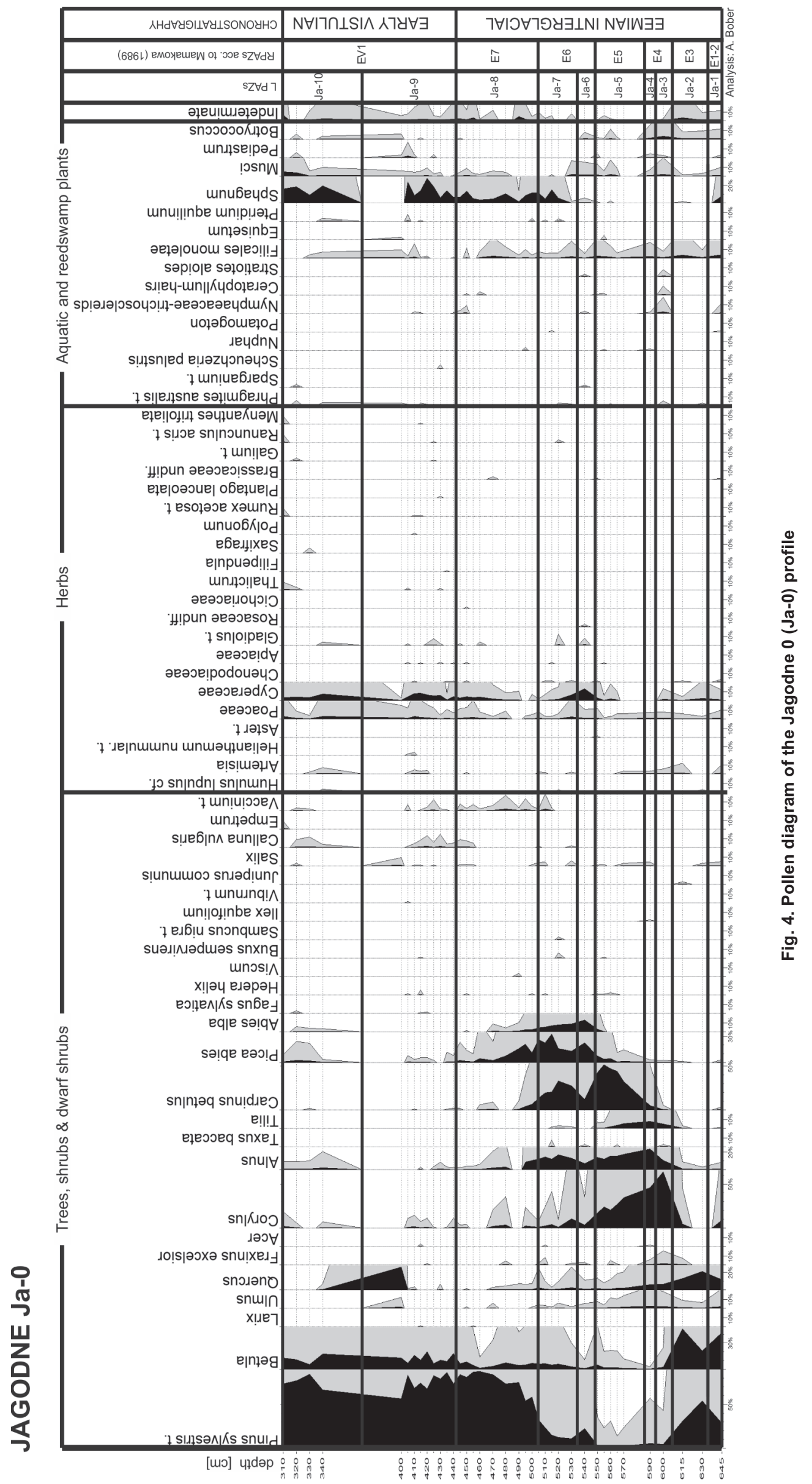




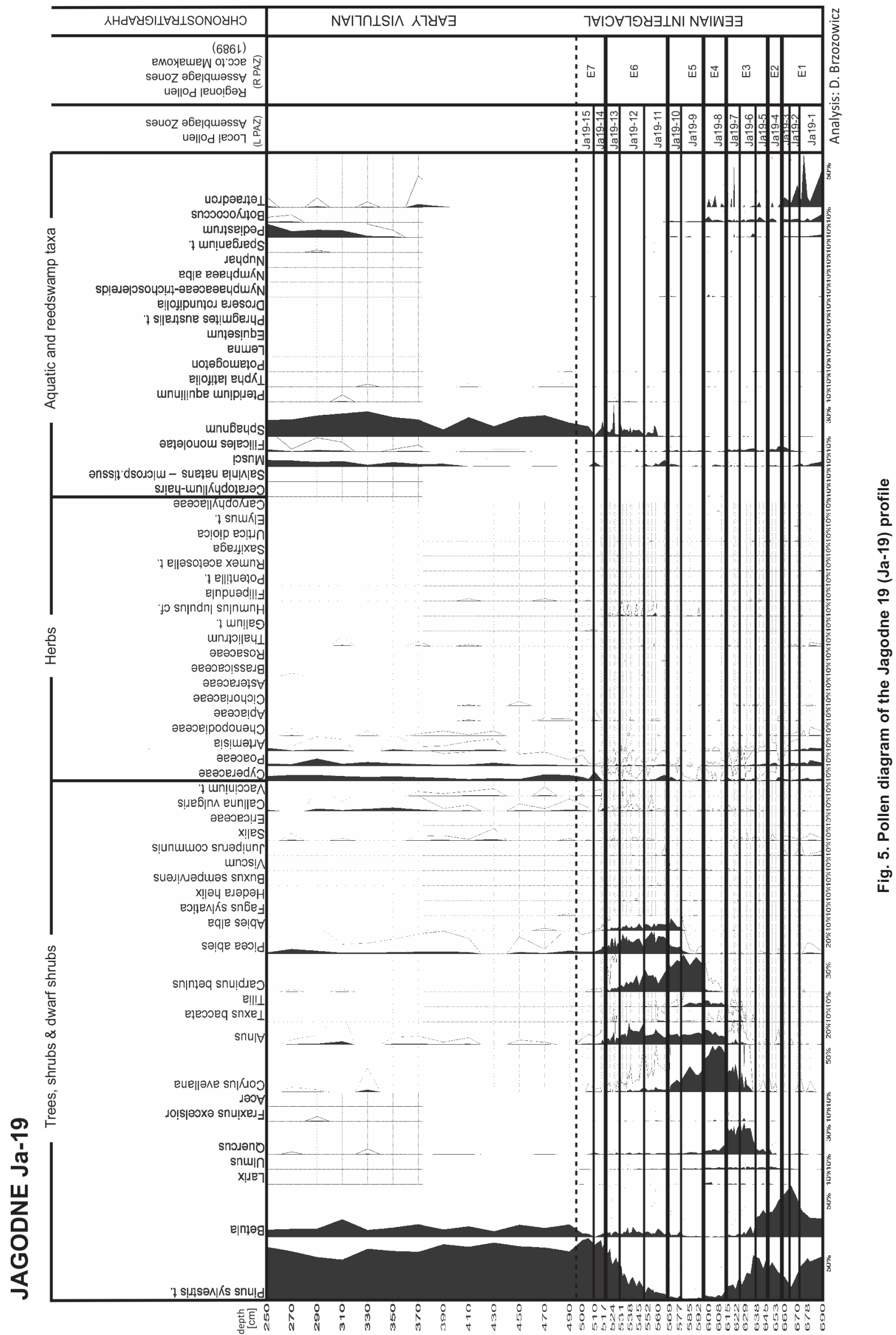


Description of the Local Pollen Assemblage Zones (LPAZs) of the Ja-19 diagram in correlation with the Ja-0 diagram and the Regional Pollen Assemblage Zones (RPAZs) acc. to Mamakowa (1989)

\begin{tabular}{|c|c|c|c|}
\hline $\begin{array}{l}\text { Corresponding } \\
\text { R PAZs acc. to } \\
\text { Mamakowa } \\
\quad(1989)\end{array}$ & $\begin{array}{l}\text { Corresponding } \\
\text { Ja-0 LPAZs } \\
\text { samples depth } \\
{[\mathrm{cm}]}\end{array}$ & $\begin{array}{l}\text { Ja-19 LPAZs } \\
\text { samples depth } \\
{[\mathrm{cm}]}\end{array}$ & Characteristic features of pollen spectra \\
\hline \multirow{3}{*}{ RPAZ E1 } & \multirow{4}{*}{$\begin{array}{c}\text { Ja-0 } 1 \\
645\end{array}$} & $\begin{array}{c}\text { Ja-19 } 1 \\
675-690\end{array}$ & $\begin{array}{c}\text { Percentages of Pinus sylvestris t. range from } 50.5 \text { to } 57.5 \% \text {, those of } \\
\text { Betula from } 26.5 \text { to } 34.5 \% \text {; continuous pollen curve of Picea and Salix } \\
\text { with values up to } 1.4 \% \text { and } 1.0 \% \text { respectively; sporadic pollen of other } \\
\text { trees (Ulmus, Quercus, Fraxinus) and Juniperus. NAP values are high, } \\
\text { with Poaceae ranging from } 3.4 \text { to } 8.0 \% \text {, Cyperaceae from } 2.3 \text { to } 4.0 \% \\
\text { and Artemisia from } 2.0 \text { to } 3.5 \% \text {. Frequent occurrence of } \\
\text { Chenopodiaceae, Thalictrum, Cichorioideae. Musci spores and algae } \\
\text { (Pediastrum, Botryococcus, Tetraedron) are very frequent. }\end{array}$ \\
\hline & & $\begin{array}{c}\text { Ja-19 } 2 \\
665-670\end{array}$ & $\begin{array}{c}\text { Sharp increase of Betula pollen values up to } 72 \% \text {, those of Pinus drop } \\
\text { to } 17 \% \text {, simultaneously a drop of Cyperaceae is observed. The values } \\
\text { of Poaceae oscillate around } 4 \% \text {. Continuous pollen curve of Ulmus oc- } \\
\text { curs. Less frequent are pollen grains of Artemisa, Chenopodiaceae and } \\
\text { Musci spores. Considerable increase of Filicales monolete is observed. } \\
\text { After a break in the samples of } 678 \mathrm{~cm} \text {, again very high values of } \\
\text { Tetraedron. Frequent occurrence of other algae (Pediastrum and } \\
\text { Botryococcus) }\end{array}$ \\
\hline & & $\begin{array}{c}\text { Ja-19 } 3 \\
660\end{array}$ & $\begin{array}{c}\text { This zone is represented by one sample in which the pollen percentages } \\
\text { of Pinus and Ulmus increase to } 28.5 \text { and } 1.3 \% \text { respectively, those of } \\
\text { Betula decrease to } 63 \% \text { and a significant drop of Poaceae and Artemi- } \\
\text { sia is observed. Salix pollen curve disappears. }\end{array}$ \\
\hline RPAZ E2 & & $\begin{array}{c}\mathrm{Ja}-194 \\
650-655\end{array}$ & $\begin{array}{c}\text { The pollen values of Pinus and Betula are on a more or less equal level } \\
\text { between } 38.0 \text { and } 51.0 \% \text {, those of Ulmus increase and attain a maxi- } \\
\text { mum of } 4.7 \% \text {, simultaneously pollen of Quercus increase to } 2.0 \% \text { and a } \\
\text { Fraxinus pollen curve starts. Again, an increase of Poaceae, } \\
\text { Cyperaceae and Artemisia percentages is observed. }\end{array}$ \\
\hline \multirow[t]{2}{*}{ RPAZ E3 } & \multirow[t]{2}{*}{$\begin{array}{c}\text { Ja-0 } 2 \\
615-630\end{array}$} & $\begin{array}{c}\mathrm{Ja}-195 \\
638-645\end{array}$ & $\begin{array}{l}\text { Betula pollen values drop to } 28.0 \% \text {, while those of Pinus increase } \\
\text { slightly to } 59.0 \% \text {. The values of Ulmus range between } 1.6 \text { and } 3.3 \% \text {. } \\
\text { The most characteristic feature of the zone is a significant increase of } \\
\text { Quercus percentages to } 7.5 \% \text {, with a simultaneous continuous pollen } \\
\text { curve of Fraxinus and the occurrence of sporadic pollen grains of } \\
\text { Corylus, Alnus, Picea and Salix. NAP values decrease, Cyperaceae } \\
\text { lowering to } 0.4 \% \text {, Poaceae to } 1.9 \% \text { and Artemisia to }<1 \% \text {. Filicales and } \\
\text { Musci spores are quite frequent. Algae (Pediastrum and Botryococcus) } \\
\text { are still observed. Tetraedron values drop considerably. }\end{array}$ \\
\hline & & $\begin{array}{c}\text { Ja-19 } 6 \\
625-635\end{array}$ & $\begin{array}{c}\text { Pollen of Quercus increases and attains its maximum of } 45 \% \text {, the val- } \\
\text { ues of Ulmus are on the same level as in the previous zone; more fre- } \\
\text { quent is Corylus pollen. The percentages of Pinus and Betula drop to } 30 \\
\text { and } 5 \% \text {, respectively. Percentages of Cyperaceae and Poaceae rise } \\
\text { again to } 5.0 \text { and } 2.7 \% \text { respectively. }\end{array}$ \\
\hline \multirow[b]{2}{*}{ RPAZ E4 } & $\begin{array}{c}\text { Ja-0 } 3 \\
600\end{array}$ & $\begin{array}{c}\mathrm{Ja}-197 \\
615-623\end{array}$ & $\begin{array}{l}\text { Pollen values of Quercus slightly decrease to } 36.0-39.5 \% \text {. Those of } \\
\text { Ulmus and Fraxinus are on the level of } 2-3 \% \text {, with maximum of } \\
\text { Fraxinus } 3.9 \% \text { in the sample at } 618 \mathrm{~cm} \text {. Percentages of Corylus in- } \\
\text { crease very sharply to } 29 \% \text {, while those of Pinus and Betula drop to } 18 \\
\text { and } 1.2 \% \text {, respectively. Continuous pollen curves of Alnus and Taxus } \\
\text { appear, with values } \sim 2 \% \text { each. Simultaneously Tilia pollen starts to oc- } \\
\text { cur regularly with values of } \sim 0.4-1.1 \% \text {. Pollen grains of Hedera and } \\
\text { Viscum occur. There is a sharp increase in Tetraedron values. }\end{array}$ \\
\hline & $\begin{array}{c}\text { Ja-0 } 4 \\
590\end{array}$ & $\begin{array}{c}\text { Ja-19 } 8 \\
600-613\end{array}$ & $\begin{array}{c}\text { A dramatic increase of Corylus pollen values to the absolute maximum } \\
\text { of } 64.0 \% \text { is the most important feature of this zone. The values of Alnus } \\
\text { increase to } 20.0 \% \text { and those of Tilia to } 8.5 \% \text {. Carpinus pollen grains } \\
\text { start to appear regularly with values up to } 1.5 \% \text {. Simultaneously the val- } \\
\text { ues of Quercus drop to } 5.2 \% \text { in the upper samples. The percentages of } \\
\text { Pinus and Betula are very low at } \sim 4 \text { and } 1 \% \text {, respectively. Poaceae and } \\
\text { Cyperaceae percentages drop to less than } 1 \% \text { each, those of Artemisia } \\
\text { to }<0.2 \% \text {. Algae are much less frequent. Nymphaeaceae trichosclereids } \\
\text { are present. }\end{array}$ \\
\hline \multirow[t]{2}{*}{ RPAZ E5 } & \multirow[t]{2}{*}{$\begin{array}{c}\text { Ja-0 } 5 \\
550-570\end{array}$} & $\begin{array}{c}\text { Ja-19 } 9 \\
580-595\end{array}$ & $\begin{array}{c}\text { A considerable decrease in the Corylus pollen values to } 19.5 \% \text { in the } \\
\text { upper sample coincides with a sharp increase in Carpinus percentages } \\
\text { up the maximum of } 52.5 \% \text { in the upper sample. Simultaneously values } \\
\text { of Ulmus and Quercus drop to } 2-3 \% \text {. Tilia and Alnus pollen values are } \\
\text { similar to the previous zone, but Taxus, Fraxinus, Betula and Pinus are } \\
\text { quite rare. Picea pollen grains occur more frequently, up to } 3.7 \% \text { in the } \\
\text { upper sample. NAP attains the lowest values in the whole pollen dia- } \\
\text { gram. }\end{array}$ \\
\hline & & $\begin{array}{l}\text { Ja-19 } 10 \\
570-575\end{array}$ & $\begin{array}{l}\text { The appearance of Abies pollen and its significant increase to } 16.0 \% \text { in } \\
\text { the upper sample accompanied by an increase in Picea up to } 11.0 \% \\
\text { and decrease of Carpinus and Corylus pollen values are the most char- } \\
\text { acteristic feature of the zone. Simultaneously, pollen of Fraxinus, } \\
\text { Ulmus, Pinus and Betula are more frequent. A sharp increase in } \\
\text { Cyperaceae pollen to } 6.5 \% \text { is accompanied by Musci spores. }\end{array}$ \\
\hline
\end{tabular}




\begin{tabular}{|c|c|c|c|}
\hline \multirow{3}{*}{ RPAZ E6 } & \multirow{3}{*}{$\begin{array}{c}\text { Ja-06 } \\
540 \\
\text { Ja-0 } 7 \\
505-530\end{array}$} & $\begin{array}{l}\text { Ja-19 } 11 \\
550-565\end{array}$ & $\begin{array}{c}\text { A further increase in pollen percentages of Picea up to the maximum of } \\
30.5 \% \text { is accompanied by a slight increase in those of Pinus (to } 12.5 \% \text { ) } \\
\text { and Betula (up to } 14.5 \% \text { ) and decrease of Abies (range between } 2.0 \\
\text { and } 10.0 \% \text { ). Carpinus values are still high (22.0-28.5\%), Alnus ranges } \\
\text { between } 11.0 \text { and } 16.0 \% \text {. The Corylus percentages drop to } \sim 3.5 \% \text {. A } \\
\text { slight decrease in Cyperaceae pollen values is accompanied by in- } \\
\text { crease of Poaceae percentages and a local maximum of Musci spores } \\
\text { (up to } 12.5 \% \text { ) at the beginning of the zone. }\end{array}$ \\
\hline & & $\begin{array}{l}\text { Ja-19 } 12 \\
530-548\end{array}$ & $\begin{array}{l}\text { A further rise in Pinus (to } 47 \% \text { ) and Betula pollen values (to } 19.0 \% \text { ) is } \\
\text { simultaneous with slight decrease and frequent changes of Picea and } \\
\text { Abies. At the same time the percentages of Alnus increase considerably } \\
\text { to } 28.5 \% \text { before dropping to } 6.5 \% \text { in the uppermost sample. Pollen per- } \\
\text { centages of Corylus range between } 0.7 \text { and } 5.7 \% \text {. More frequent is the } \\
\text { pollen of Salix and Calluna. Musci spores are less frequent than in the } \\
\text { previous zone and Sphagnum spores occur and form a continuous } \\
\text { spore curve with increasing values. Single spores of Pteridium } \\
\text { aquilinum draw attention. Pediastrum and Botryococcus colonies disap- } \\
\text { pear almost completely. }\end{array}$ \\
\hline & & $\begin{array}{l}\text { Ja-19 } 13 \\
520-525\end{array}$ & $\begin{array}{l}\text { Pollen percentages of Pinus rise to } 63.5 \% \text {, Picea and Alnus drop to } \\
\sim 8.5 \% \text {, and Abies to } 1.5 \% \text {. Carpinus pollen values attain } 3.5-4.0 \% \text {. Pol- } \\
\text { len grains of other trees occur quite infrequently. Among NAP, } \\
\text { Cyperaceae and Poaceae attain } 2.5 \text { and } 1.5 \% \text {, respectively. Spores of } \\
\text { Sphagnum attain the maximum value of } 51.5 \% \text { in the whole profile, and } \\
\text { drop dramatically in the uppermost sample of the zone. }\end{array}$ \\
\hline RPAZ E7 & $\begin{array}{c}\text { Ja-0 } 8 \\
445-500\end{array}$ & $\begin{array}{l}\text { Ja-19 } 14 \\
510-517\end{array}$ & $\begin{array}{l}\text { Values of Pinus sylvestris t. are very high }(73.5-85.0 \%) \text { while frequen- } \\
\text { cies of Betula are low (0.8-6.3\%); percentages of Picea drop from } 6.0 \text { to } \\
2.3 \% \text { in the uppermost sample, values of Alnus are around } 1 \% \text {; pollen } \\
\text { grains of Quercus and Corylus are quite frequent, with sporadic occur- } \\
\text { rences of Fraxinus, Ulmus, Abies; very high values of Cyperaceae up to } \\
13 \% \text { in samples from the depth of } 510 \mathrm{~cm} \text {, accompanied by abundant } \\
\text { Musci spores. Pollen values of Poaceae rise to } 2.3 \% \text { in the uppermosr } \\
\text { sample; sporadic pollen of Apiaceae, Filipendula. High values of Sphag- } \\
\text { num occur again and range between } 16.0 \text { and } 28.0 \% \text {. }\end{array}$ \\
\hline Early Vistulian & $\begin{array}{c}\text { Ja-0 } 9 \\
400-440 \\
\text { Ja-0 } 10 \\
310-340\end{array}$ & $\begin{array}{l}\text { Ja-19 } 15 \\
250-490\end{array}$ & $\begin{array}{l}\text { Dominance of Pinus sylvestris t., values of Betula range from } 9.0 \text { to } \\
24.0 \% \text {; significant increase in NAP values, with Poaceae ranging from } \\
1.0 \text { to } 10.0 \% \text {, Cyperaceae from } 2.7 \text { to } 9.0 \% \text {, Artemisia range from } 0.6 \text { to } \\
4 \% \text {, frequent Chenopodiaceae pollen (up to } 1.0 \% \text { ) and sporadic occur- } \\
\text { rences of Thalictrum, Apiaceae, Cichoriaceae, Filipendula and Typha } \\
\text { latifolia pollen. Musci and Sphagnum spores occur very frequently up to } \\
8.0 \text { and } 34.5 \% \text {, respectively. Spores of Filicales monolete start to form a } \\
\text { continuous curve, in the upper part of the zone with values up to } 3 \% \text {. }\end{array}$ \\
\hline
\end{tabular}

2001). At the time of this zone riparian assemblages were not subjected to radical changes. Most probably alder-ash forests thrived, as did alder carrs. The considerable share of Picea abies pollen suggests an admixture of spruce, probably in alder forests.

In Ja-19 LPAZ 10 the significant increase in Abies pollen values suggests the local occurrence of fir, probably in the same assemblages as spruce. Research on modern pollen deposition of Abies indicates that heavy fir pollen grains are not spread long-distance in high amounts (Pidek et al., 2013).

In Ja-19 LPAZ 11, the shares of several thermophilic taxa, including Carpinus, Tilia, Ulmus and Corylus decline. In contrast, the share of Picea pollen increases significantly and is accompanied by still considerable pollen values of other conifers Abies and Pinus sylvestris. Single pollen grains of Fagus sylvatica and Buxus sempervirens also occur, indicating humid climate conditions.

In Ja-19 LPAZ 12, a further rise of Pinus sylvestris t. pollen suggests the spread of pine into the various habitats. However, plants indicating a warm climate with gentle winters still occur throughout the zone. These include Viscum, Hedera helix, and Fagus sylvatica. The share of Alnus is somewhat higher than in Ja-19 LPAZ 11, while Salix pollen grains begin to appear regularly. In the upper part of the zone, spores of Sphagnum start to occur in considerable numbers, which testifies to the overgrowing of the palaeolake and considerable habitat changes towards a raised bog.

Such changes definitely occurred as a result of climate cooling. The upper sample of the zone shows a very sharp de- crease in spruce, fir and alder. A rapid increase in pine, and further increase in Sphagnum and the absence of indicators of a warmer climate, suggest a period of considerable cooling in which pine could find favourable conditions for its development.

In Ja-19 LPAZ 13 Pinus sylvestris t. pollen is largely predominant. The composition of pollen spectra reflects the broad expansion of boreal pine forests, with a slight admixture of birch and spruce. In humid habitats alder still played an important role, at least in the older part of the zone, as suggested by the high values of Alnus pollen. Towards the top of the zone, the increase in Cyperaceae, Apiaceae and other NAP suggest a gradual increase in open areas overgrown by sedges and other herbaceous plants, especially those typical of wet habitats. The sporadic pollen grains of thermophilic trees were, most probably, redeposited from older deposits.

Ja-19 LPAZ 14, while still containing a very high share of Pinus sylvestris t., is characterized by an increase in the amount of herbaceous plant pollen and Sphagnum spores, suggesting further expansion of open areas and peatbogs in the landscape.

\section{PLANT MACROFOSSIL ANALYSIS}

Based on the results of the Ja-19 core, 11 Local Macrofossil Assemblage Zones (LMAZs) were distinguished (Fig. 6). Their interpretation in relation to the pollen diagram (Fig. 5) sheds light upon the evolution of the Jagodne sedimentary basin, as well as on local palaeohydrological changes. 


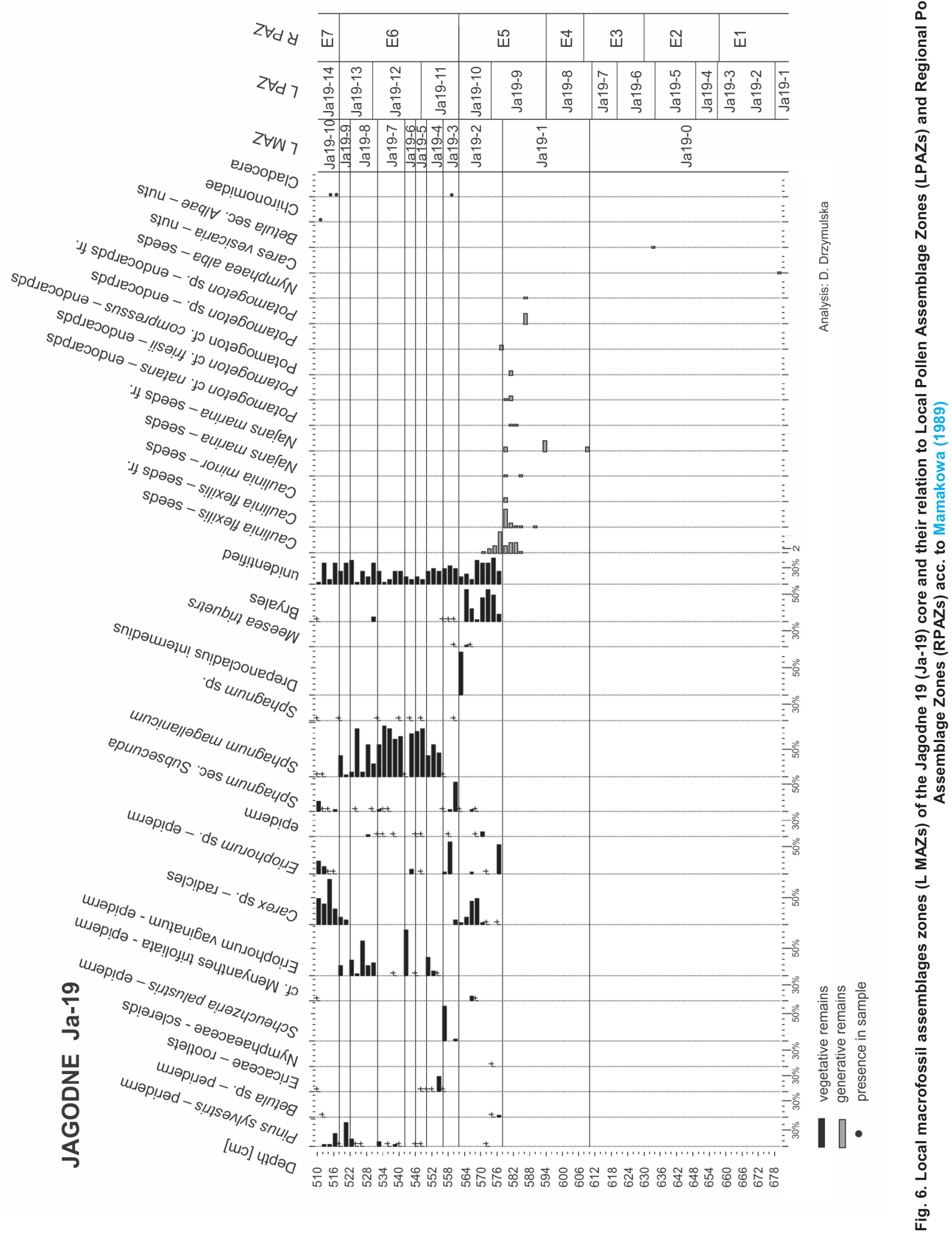


The almost complete absence of macrofossils (except for single nuts of sedges and tree birches) in the gyttja samples from the depth of $610-680 \mathrm{~cm}$, included as Ja-19 LMAZ 0, makes delimitation of the boundary with the following zone (Ja-19 LMAZ 1) arbitrary. The palynological diagram documents in this period the presence of Potamogeton and numerous algae (Tetraedron, Pediastrum, and Botryococcus). The Tetraedron percentage curve shows sharp fluctuations, which indicate population changes probably related to dynamic changes in the lake water level. Ja-19 LMAZ 0 corresponds to the initial phases of the Eemian Interglacial from RPAZs E1 to E3. At the depth of $655 \mathrm{~cm}$, there is a lithological boundary where the gyttja deposits end and the shales begin.

Generative remains of aquatic plants appear from the sample at $608 \mathrm{~cm}$ depth and are quite frequent up to that of $578 \mathrm{~cm}$ (Ja-19 1 LMAZ). These include seeds of Najas marina, Caulinia flexilis, Nymphaea alba and macroremains of several Potamogeton species. The presence of a eutrophic water reservoir indicated by these macroremains is also documented in the palynological diagram by the presence of Nymphaeaceae trichosclereids, Potamogeton pollen, Pediastrum, and Botryococcus algae. During this time, however, the Tetraedron population was declining. This state of the palaeolake corresponds to the time period from the declining oak phase (RPAZ E3), through the hazel phase (RPAZ E4), to the first part of the hornbeam phase (RPAZ E5) of the Eemian Interglacial. The upper limit of Ja-19 LMAZ 1 coincides not only with the limit of the pollen zone J-19 LPAZ 9, but is also the clearly defined lithological boundary at which the organic shales end and peat begins.

Starting from zone Ja-19 LMAZ 2 macrofossils become very abundant. Here, the change in taxonomic composition distinguished clearly points to the presence of fen during Ja-19 LMAZ 2. This was a moss-sedge community that was overgrowing the water body. Nevertheless, the remains of aquatic plants were still present (e.g., Caulinia flexilis seeds and Potamogeton endocarps). This zone corresponds to the J-19 LPAZ 10 and the older part of Ja-19 LPAZ 11, and thus corresponds to the declining part of RPAZ E5 and the beginning of E6.

The further development of the fen is documented starting from the Ja-19 LMAZ 3. This zone indicates the existence of a transitional fen with the presence of Scheuchzeria palustris, Eriophorum sp. and Sphagnum belonging to the Subsecunda section, including Sphagnum subsecundum.

The zones from Ja-19 LMAZ 4 to 8, in terms of taxonomic composition and abundance of macrofossils, correspond to a raised bog type of vegetation with abundant Sphagnum magellanicum, Eriophorum vaginatum, and shrubs of the Ericaeae family, as well as the occasional presence of Scots pine.

In Ja-19 LMAZ 9 the composition of plant macroremains indicates a further transformation of the raised bog into a transitional fen, with encroaching sedges. The zones from Ja-19 LMAZ 3 to 9 are within the Picea-Abies phase of the Eemian (E6 RPAZ E6).

A more clearly expressed picture of the transitional fen, with sedges and peat mosses from the Subsecunda section, Eriophorum sp. and pine, is documented in J-19 LMAZ 10. This zone correlates with the declining (Pinus) phase of the Eemian Interglacial corresponding to RPAZ E7.

From the results above it can be concluded that the LMAZs Ja-19 1-10 clearly document the stages of transformation of the palaeolake into a peat bog. This began very early, in the hornbeam period (E5 RPAZ). Furthermore, Ja-19 LMAZ 3 reveals the transformation of a bog with dominating moss-sedge communities, into a transitional type of bog with Sphagnum from the
Subsecunda section, and then into a raised bog with Sphagnum magellanicum, Eriophorum vaginatum, and dwarf shrubs. In the Ja-19 LMAZ 10, which correlates with the beginning of the Pinus phase (RPAZ E7), there was a return to a transitional fen with sedges and Sphagnum from the Subsecunda section, as well as Eriophorum sp. and pine.

\section{DISCUSSION}

\section{THE LOWER BOUNDARY OF THE EEMIAN INTERGLACIAL}

Usually, in palynological diagrams, the boundary between glacial and interglacial is characterized by a significant increase in tree-birch pollen, and a simultaneous decrease in NAP values. This means that the area is taken over by photophilous, pioneering communities of boreal birch forests that enter the area released from ice cover, untile then occupied by steppe-tundra communities, which disappear when the average temperature of the warmest month is at least $10^{\circ} \mathrm{C}$. Relatively quickly, as a result of natural succession, these pioneer forests are replaced by mixed pine and birch forests, followed by trees of later succession stages. Such a traditional approach to the transitional boundary from late-glacial communities to pioneering tree birch communities already belonging to the interglacial encounters difficulties in the case of the Jagodne Ja-19 pollen diagram, as well as in some other high-resolution profiles of the Late Saalian/Eemian Interglacial.

There are relatively few profiles analysed at high resolution where this boundary can be traced. However, Mamakowa (1989) considered several of these, including the Warsaw-Wawrzyszew profile analysed by Krupiński and published later by Krupiński and Morawski (1993). This profile is situated quite close to the Garwolin Plain. In the Warszawa-Wawrzyszew pollen diagram, the late glacial sequence is tripartite. The lowermost zone (NAP-Juniperus LPAZ) is dominated by herb pollen and Juniperus pollen at levels reaching $4.7 \%$. This is followed by an interstadial zone (Hippophaë-Betula LPAZ), with a high culmination of Hippophaë (up to $40 \%$ ) and a very high culmination of Betula (>78\%). At the same time, the NAP falls $(\sim 10 \%)$. The upper zone of the late glacial succession is the NAP-Hippophaë-Juniperus LPAZ, which is characterized by the recurrence of high NAP values, together with Juniperus and a still considerable proportion of Hippophaë. The upper boundary of the late glacial succession in this profile is placed at the fall in pollen values of herbs and the rise of Pinus pollen values with simultaneous relatively high values of Betula pollen.

The problem of the lower limit of the Eemian Interglacial has recently been discussed in detail by Kupryjanowicz et al. (2021), in reference to another palynological diagram from the Garwolin Plain - Wola Starogrodzka. In this profile, within the extensive Late Saalian succession, the pollen spectra record two climatic oscillations of stadial character, separated by an interstadial. The stadial section that preceded the Eemian in the Wola Starogrodzka profile is $40 \mathrm{~cm}$ thick (depth $242-282 \mathrm{~cm}$ ) and was analysed palynologically at $2 \mathrm{~cm}$ resolution. Apart from the high proportion of pine pollen and a significant proportion of spruce pollen, there is a continuous curve of a few percent share of dwarf birch (Betula nana), a large proportion of grasses (Poaceae), and a continuous low percentage of Artemisia and Cyperaceae values. The continuous presence of Ceratophyllum and Nymphaeaceae (including Nuphar) was noted among aquatic plant taxa and Typha latifolia among rushes. The presence of the latter taxon clearly indicates that the average temperature in July was at least $14^{\circ} \mathrm{C}$ (Kolstrup, 1980). Thus, it can be assumed that, on the Garwolin Plain, the 
termination of the Late Saalian was seasonally quite warm (warm summers), while climate could have continental features and winter could have been harsh, allowing tundra birch and boreal spruce, most presumably Picea obovata, to survive.

In the Wola Starogrodzka profile discussed (Kupryjanowicz et al., 2021), the transition from glacial to interglacial is placed at the significant increase of the share of trees and shrub pollen and the appearance of the continuous, low-percentage pollen curve of the elm. At the same time, the continuous curve of Quercus had already begun, while the proportions of pine and NAP slightly fall. However, there are still high values of Poaceae, Artemisia, and Cyperaceae, as in the entire duration of the preceding stadial.

The Ja-0 pollen diagram does not contain a section that can be considered a transition from Late Glacial to interglacial conditions. On the other hand, when observing the course of the percentage curves discussed in the Ja-19 diagram, it can be concluded that Ja-19 LPAZ 1 zone has transitional features between the youngest section of the Late Glacial and the first zone of the Eemian Interglacial (E1 RPAZ). These include features similar to those recorded on the Wola Starogrodzka pollen diagram: a high proportion of pine $(\sim 50 \%)$ and NAP (with high values of Artemisia - up to $4.5 \%$, Poaceae - up to $8 \%$ and Cyperaceae - up to $4 \%$ ), and, additionally, the continuous presence of spruce pollen (up to 1.5\%). Kupryjanowicz and Granoszewski (2018) considered such a composition of pollen spectra as representative of the boundary between the Late Glacial and the interglacial. A similar conclusion can be derived from the pollen diagram from Warszawa-Wawrzyszew (Krupiński and Morawski, 1993).

Only the next level (Ja-19 LPAZ 2) shows an increase in the value of pollen of tree birches, typical of the beginning of the interglacial in the diagrams discussed, including that from Wola Starogrodzka (Kupryjanowicz et al., 2021).

THE SUCCESSION OF THE EEMIAN INTERGLACIAL AT THE JAGODNE SITE IN COMPARISON TO OTHER SITES ON THE GARWOLIN PLAIN AND IN POLAND

On the basis of the appearance, course and culmination of the percentage curves of key taxa for the Eemian, it can be concluded that the beginning of this succession proceeded without major disturbances through the E2 phase (Pinus-Betula-Ulmus), the E3 phase (Quercus) and the E4 phase (Corylus). In the last of these, the culmination of lime pollen draws special attention. Tilia reaches high percentages from the beginning of the zone and has a culmination almost simultaneous with that of Corylus, which indicates the occurrence of variant B1, called by Mamakowa (1989) "the early lime with late culmination". This author also considered the pollen diagram from Warszawa-Wawrzyszew (Krupiński and Morawski, 1993) as representing the same variant. Moreover, this course of the culmination of both taxa was observed in the Struga pollen diagram (Bober et al., 2018) from the Garwolin Plain, whereas the high-resolution palynological data from the nearby Kozłów (K2-19) profile (Fig. 1) leaves the question of an early lime variant open, as the sedimentary succession between the oak and hazel levels (E3/E4 transition) seems to be disturbed (Pidek et al., 2021). Certainly, however, in the diagram from the Wola Starogrodzka profile, lime culminates almost at the same time as hazel, therefore it represents the variant with the early lime. Thus, it can be inferred that these sites from the Garwolin Plain document the Eemian succession in its variant with early lime. This is also reasonably related to the data from other profiles of central Poland with the same variant - positions from the vicinity of Warsaw: Warszawa-Żoliborz and Warszawa-Wola (Ra-
niecka-Bobrowska, 1954) and Góra Kalwaria (Sobolewska, 1961), among other sites.

The greatest differences between the course of the succession at the Jagodne and other Eemian sites from the Garwolin Plain occur at RPAZ E5 and E6. Comparison with the key pollen diagram from the Kozłów K2-19 profile, where the hornbeam phase (E5 RPAZ) is recorded in a very thick 4-meter layer of gyttja, suggests that the thin sedimentary section in the Jagodne Ja-19 core corresponding to RPAZ E5 may not contain the complete record of the Carpinus phase, the duration of which was estimated at 7300 years by varve counting in the Bispingen/Luhe core (Lauterbach et al., 2012). The division of RPAZ E5 into 4 subzones (according to the new, detailed palynostratigraphy of the Eemian Interglacial by Kupryjanowicz and Granoszewski, 2018) allows for a more detailed interpretation, not only in terms of the development of vegetation and the evolution of the palaeolake, but also concerning palaeoclimate.

Apart from the obvious domination of Carpinus, the hornbeam phase of the Eemian interglacial is characterized by the Alnus culmination and falling shares of Corylus and Tilia.

The oldest subzone, E5a, of Carpinus-Corylus-Tilia, corresponds to the older part of Ja-19 LPAZ 9. This is characterized by a sharp increase in the Carpinus curve and the presence of a still relatively high share of Corylus and Tilia. In contrast, the E5b Carpinus-Corylus subzone is characterized by an increasing share of Carpinus, a decrease in the percentages of Tilia, as well as a still relatively high share of Corylus, and may correspond to the younger part of Ja-19 LPAZ 9. The E5c Carpinus subzone corresponds to the Carpinus peak and a significant decline in Corylus. It can be found in the sample at $575 \mathrm{~cm}$ depth in Ja-19 LPAZ 10.

While the whole E5d subzone might not be fully represented in the Ja-19 diagram, traces of this subzone are detectable probably at the decline of Ja-19 LPAZ 10 (samples $569-570 \mathrm{~cm}$ ). The E5d subzone is characterized by the appearance and slow increase of Picea and Abies and by the slow decline of Carpinus. At the same time, a sharp lithological change of the gyttja deposits into peat occurs (at the depth of $575 \mathrm{~cm}$ ). This is also consistent with changing plant macrofossil assemblages at $578 \mathrm{~cm}$ depth (Fig. 6).

The following samples $(565-519 \mathrm{~cm})$ already exhibit features typical for RPAZ E6 - in its oldest part, i.e. a significant increase in Picea, with falling, but still high Carpinus values.

Thus, by comparison to the full RPAZ E5 record in the Kozłów K2-19 pollen diagram (covering $4 \mathrm{~m}$ of deposits), it can be concluded that the hornbeam phase at the Jagodne site is reduced not only in terms of the thickness of the sedimentary section representing E5 $(26 \mathrm{~cm})$, but also in the completeness of the sedimentation process in RPAZ E5. Moreover, individual E5 a-d subzones are represented in Ja- 19 by only $2-3$ samples, despite the very high sampling resolution of 1 to $5 \mathrm{~cm}$ in the interglacial section.

In the Ja-19 profile, RPAZ E6 is recorded in a sedimentary layer thicker than that of RPAZ E5 and can be divided into subzones according to the proposal of Kupryjanowicz and Granoszewski (2018).

The E6a subzone (Picea-Carpinus) is characterized by the strong increase in Picea with a decreasing, but still high, proportion of Carpinus and corresponds to the Ja-19 LPAZ 11. Moreover, in the following subzone E6b (Picea-Abies), with the continued increase of Picea percentages, a maximum of Abies would be expected. However, in the Ja-19 diagram, the fir maximum is observed at the transition between Ja-19 LPAZs 10 and 11. This inconsistency can be related to changes of the palaeoenvironment. The presence of sedges and mosses is shown by their higher percentages in the pollen diagram. Most 
probably spruce occupied the habitat of the overgrown lake and thus the fir pollen record did not reflect the true proportion of this tree in the surrounding forests. However, the E6c (Picea) subzone, with the maximum of Picea pollen, and the E6d subzone, with increasing values of Pinus pollen, can be traced in Ja-19 LPAZs 11-13.

Full representation of the Carpinus (RPAZ E5) and Picea-Abies (RPAZ E6) phases is absent in many Eemian profiles from Poland, possibly because of a fall in water level at that time. Our results from the Jagodne site are in good agreement with the palynological results from the closest Eemian site, Żabieniec (Hrynowiecka et al., 2020), where a distinct decrease in the proportion of Carpinus in E5 RPAZ was interpreted as a clear manifestation of water level decrease and transformation of a shallowing lake into a peat bog. Interestingly, in the regional context, our data from the Jagodne site, where the Carpinus zone is recorded in a $15 \mathrm{~cm}$-thick layer, strongly contrasts with the nearby Kozłów site, but agree with the pollen data from the Wola Starogrodzka site (Kupryjanowicz et al., 2021). These kinds of regional inconsistencies are not uncommon - there are known sites with palaeohydrological disturbances in the RPAZ E5 located near sites with a complete Eemian succession (Kupryjanowicz, 2008). Indeed, the Garwolin Plain adjoins the region of Płock, in which the Studzieniec site showing a complete Eemian sequence and is located close to other palaeolakes that clearly reflect a decrease in water levels and sedimentation gaps (Mirosław-Grabowska and Niska, 2007).

Palynological studies of Eemian fossil lakes from different regions of Poland suggest that the water level could have fallen significantly in the RPAZ E5, e.g. Główczyn (Niklewski, 1968), Besiekierz (Janczyk-Kopikowa, 1991), Dziewule (Bińka and Nitychoruk, 2003). A similar drop in water level in E5 was reported by Roman et al. (2021). These authors stress that for most Eemian lakes, this period is considered to be critical and, most probably, is related to a lowering in water level. These changes in water level most probably were not related to any drastic climate changes in terms of temperature; the older part of the hornbeam phase constitutes the thermal optimum of the last interglacial (Cheddadi et al., 1998; Karabanov et al., 2000; Granoszewski, 2003; North GRIP members, 2004; Kupryjanowicz, 2008). However, Cheddadi et al. (1998) showed that precipitation from the very beginning of the Carpinus phase dropped in central and eastern Europe by 200-300 mm yr. The studies by Kupryjanowicz (2008) in the northern Podlasie region suggest that while no drop in temperature was apparent during the hornbeam phase, a significant drop in humidity was observed. The latter was indicated by lower water levels in several lakes and mires. The lakes Kozłów (Pidek et al., 2021) and Struga (Zalat et al., 2021) fit this pattern. Moreover, in the Kozłów K2-19 pollen, in the final part of RPAZ E5c, no rapid changes in vegetation were observed, apart from the increasing role of Picea in the forests, whereas, in contrast, the diatom assemblages demonstrate a sudden lowering of the water level in the fossil lake, although the lake did not stop functioning (Pidek et al., 2021). Examples of transformation of Eemian palaeolakes into peatbogs in Western Europe are very rare. One of these is the Hinterste Mühle site in northern Germany, where, the Carpinus phase deposition of lacustrine sediments was replaced by peat accumulation (Börner et al., 2018).

The lowering of water level noted in the early E5 is often evident also in the late E6. Indeed, such examples are also reported from NE Poland (Kupryjanowicz, 2008). The recession of all thermophilous trees observed in RPAZ E6 not only attests to significant changes in forest composition but also points towards climate deterioration. Nevertheless, Kupryjanowicz et al.
(2018) concluded that even in the region of northern Podlasie, the drop of summer mean temperature was not very sharp and the mean July temperature was not lower than $+17^{\circ} \mathrm{C}$, as indicated by the presence of Viscum. This points to a warm summer, and, consequently, the observed hiatuses may be the result of the increasing continentality of climate.

A very sharp increase in Pinus simultaneous with a dramatic decrease in pollen values of most other trees marks the final zone of the interglacial (RPAZ E7). In the Ja-19 diagram (Fig. 5), despite the considerable increase of Cyperaceae (up to $13 \%$ ) and Musci (one sample at $5.10 \mathrm{~m}$ ), Pinus values steadily increase. However, despite the very high resolution of the pollen diagram, it cannot be decided whether these increases may indicate a slight cooling during the pine phase, or a temporary habitat change. Unfortunately, the record of the Ja-19 profile does not allow further investigation of the suggested cooling in RPAZ E7. Such a climate change was discussed by Mamakowa (1989), Granoszewski (2003), Kupryjanowicz et al. (2005; 2016) and Boettger et al. (2009).

\section{THE UPPER BOUNDARY OF THE EEMIAN INTERGLACIAL}

This upper boundary of the Eemian Interglacial will be the subject of a detailed further study because the current sampling resolution in the upper part of the succession studied (from 250 to $490 \mathrm{~cm}$ ) is quite low $(20 \mathrm{~cm})$. Taking into account other diagrams with a recorded Eemian-Early Vistulian succession, one may expect a sharp increase in NAP (with a maximum of Artemisia) at the transition from the Pinus phase of the interglacial to the glacial. Kupryjanowicz and Granoszewski (2018) call this first glacial zone Poaceae-Artemisia-Betula nana. This has not so far been found in the Jagodne profile. This zone may appear within the $20 \mathrm{~cm}$ section of peat by increasing the sampling resolution.

The problem with the completeness of the record arises when we consider the sand layers in the upper peat units. Their presence suggests dynamic changes in the palaeoenvironment and possible hiatuses. Despite the low resolution of pollen data in this section of the Ja-19 profile, the observed fluctuations in the pollen curves of various taxa of herbaceous plants may indicate the occurrence of stadial/interstadial oscillations. On the other hand, an alternative interpretation is also possible. The 250-490 cm section may still represent RPAZ E7 of the Eemian Interglacial. However, to ascertain this, further studies including of non-pollen palynomorphs (NPPs) are necessary.

\section{CONCLUSIONS}

Jagodne is one of several new sites encompassing the Eemian Interglacial on the Garwolin Plain, which is part of the southern edge of an extensive Eemian lakeland. The results of the geological survey as well as detailed palaeobotanical data correlated to other sites revealed its significance for the reconstruction of Eemian environmental changes in this region.

In this work, pollen analysis was applied to two cores of biogenic deposits (Ja-0 and Ja-19). Additionally, plant macrofossil assemblages were determined for the Ja-19 core. The resultant pollen diagrams have been divided into local pollen assemblage zones (LPAZs) and cover the whole Eemian Interglacial and part of the following Early Vistulian. They have been correlated with regional pollen assemblage zones (RPAZs) for the Eemian Interglacial E1-E7 analysed by Mamakowa (1989). The hornbeam phase (E5 RPAZ) has been divided into subzones and compared to the corresponding divi- 
sion of the very long, fully represented E5 RPAZ in the Kozłów K2-19 pollen diagram elaborated at high resolution. The comparison revealed a sedimentary hiatus in RPAZ E5 at Jagodne, attributed to significant palaeohydrological changes occurring widely in this zone.

Among the other recently studied sites from Garwolin Plain, the Jagodne site is a further example of an Eemian succession in its variant with "early lime".

Another specific feature of the Jagodne site is the rapid terrestrialisation of the palaeolake and its transformation into a peatbog. This occurred at the end of the hornbeam phase. The peatbog developed for a long time as shown by its thick covering of Early Vistulian Spaghnum peats. Since the Eemian gyttjas are rich in non-pollen palynomorphs as well as in Cladocera remains, further detailed palaeoecological analysis of the entire limnic sedimentary succession may help resolve some palaeoecological, palaeohydrological, and palaeoclimatic problems related to the earlier oak and hazel phases of the optimum of the Eemian Interglacial - including testing of the hypothesis regarding the highest water level during the hazel phase (RPAZ E4) and rapid drying in the hornbeam phase (RPAZ E5). Further palynological studies should also help identify the cold climate oscillation suggested at the decline of the E7 (Pinus) RPAZ.

Acknowledgements. The research was financed by the National Science Centre, Poland, project No. 2017/27/B/ST10/ 01905. The authors want to thank the reviewers, Prof. D. Magri and Prof. M. Roman, whose valuable comments helped to improve the first version of this manuscript.

\section{REFERENCES}

Berglund, B.E., Ralska-Jasiewiczowa, M., 1986. Pollen analysis. In: Handbook of Holocene Palaeoecology and Palaeohydrology (ed. B.E. Berglund). John Wiley \& Sons, Chichester.

Bińka, K., Nitychoruk, J., 2003. The Late Saalian, Eemian and Early Vistulian pollen sequence at Dziewule, eastern Poland. Geological Quarterly, 47 (2): 155-168.

Bober, A., Pidek, I.A., Żarski, M., 2018. Late Saalian and Eemian Interglacial at the Struga site (Garwolin Plain, central Poland). Acta Palaeobotanica, 58: 219-229.

Boettger, T., Novenko, E.Y., Velichko, A.A., Borisova, O.K., Kremenetski, K.V., Knetsch, S., Junge, F.W., 2009. Instability of climate and vegetation dynamics in Central and Eastern Europe during the final stage of the Last Interglacial (Eemian, Mikulino) and Early Glaciation. Quaternary International, 207: 137-144.

Börner, A., Hrynowiecka, A., Stachowicz-Rybka, R., Niska, M., Kuznetsov, V., Maksimov, F., Petrov, A., Moskal - del Hoyo, M., 2016. Palaeoecological investigations of the Eemian Interglacial peat sequence Neubrandenburg-Hinterste Mühle (Mecklenburg-Western Pomerania. NE Germany. Streszczenia. XXIII Konferencja Stratygrafia Plejstocenu Polski. Biała Podlaska/Brest, 5-9.09.2016: 63-66.

Bruj, M., Roman, M., 2007. The Eemian lakeland extent in Poland versus stratigraphical position of the Middle Polish Glaciations (in Polish with English summary). Biuletyn Państwowego Instytutu Geologicznego, 425: 27-34.

Cheddadi, R., Mamakowa, K., Guiot, J., de Beaulieu, J.L., Reille, M., Andrieu, V., Granoszewski, W., Peyron, O., 1998. Was the climate of the Eemian stable? A quantitative climate reconstruction from seven European pollen records. Palaeogeography, Palaeoclimatology, Palaeoecology, 143: 73-85.

Cohen, K.M., Gibbard, P.L., 2019. Global chronostratigraphical correlation table for the last 2.7 million years, version 2019 QI-500. Quaternary International, 500: 20-31.

Granoszewski, W., 2003. Late Pleistocene vegetation history and climatic changes at Horoszki Duże, E Poland: a palaeobotanical study. Acta Palaeobotanica, Supplementum 4: 3-95.

Grosse-Brauckmann, G., 1972. Über pflanzliche Makrofossilien mitteleuropäischer Torfe. I. Gewebereste krautiger Pflanzen und ihre Merkmale. Telma, 2: 19-55.

Grosse-Brauckmann, G., 1974. Über pflanzliche Makrofossilien mitteleuropäischer Torfe. II. Weitere Reste (Früchte und Samen. Moose u.a.) und ihre Bestimmungsmöglichkeiten. Telma, 4: 51-117.

Grosse-Brauckmann., G., Streitz, B., 1992. Über pflanzliche Makrofossilien mitteleuropäischer Torfe. III. Früchte und
Samen. Moose und einige Gewerbe (Fotos von fossilen Pflanzenresten). Telma, 22: 53-102.

Hrynowiecka, A., Brzozowicz, D., Żarski, M., Stachowicz-Rybka, R., Pidek, I.A., 2020. Record of climate and palaeoenvironment changes in the fossil Eemian lake in Żabieniec (Central Poland). Proceedings of INQUA SEQS 2020: 55.

Janczyk-Kopikowa, Z., 1991. Palynostratigraphy of the Pleistocene in Poland and the problem of the age of deposits from Besiekierz (Central Poland). Annales Universitatis Mariae Curie-Skłodowska. Sectio B. Geographia, Geologia, Mineralogia et Petrographia, 46: 111-128.

Janczyk-Kopikowa, Z., 1974. The Eemian Interglacial sediments at Błonie near Warsaw. Bulletin of the Polish Academy of Sciences, Earth Sciences, 22: 147-150.

Karabanov, E.B., Propenko, A.A., Williams, D.F., Khursevich, G.K., 2000. Evidence for mid-Eemian cooling in continental climatic record from Lake Baikal. Journal of Paleolimnology, 23: 365-371.

Kolstrup, E., 1980. Climate and stratigraphy in northwestern Europe between $30,000 \mathrm{BP}$ and 13,000 $\mathrm{BP}$, with special reference to the Netherlands. Mededelingen Rijk Geologische Dienst, 32: 181-253.

Krupiński, K.M., Kucharska, M., 2001. Eemian Interglacial deposits at Dobre on the Kałuszyn Plateau (eastern Poland) (in Polish with English summary). Przegląd Geologiczny, 49: 616-620.

Krupiński, K.M., Morawski, W., 1993. Geological position and polIen analysis of Eemian Interglacial sediments of Warsaw-Wawrzyszew. Acta Palaeobotanica, 33: 309-346.

Kupryjanowicz, M., 2008. Vegetation and climate of the Eemian and Early Vistulian lakeland in northern Podlasie. Acta Palaeobotanica, 48: 3-130.

Kupryjanowicz, M., Granoszewski, W., 2018. Detailed palynostratigraphy of the Eemian Interglacial in Poland. In: Eemian history of vegetation in Poland based on isopollen maps (eds. M. Kupryjanowicz, D. Nalepka, E. Madeyska and Ch. Turner): 17-20. Szafer Institute of Botany, Polish Academy of Sciences, Kraków.

Kupryjanowicz, M., Żarski, M., Drzymulska, D., 2003. Kontrowers - a new locality of the Eemian interglacial and the Early Vistulian at Żelechów Upland (eastern Poland). Acta Palaeobotanica, 43: 77-90.

Kupryjanowicz, M., Ciszek, D., Mirosław-Grabowska, J., Marciniak, B., Niska, M., 2005. Two climatic oscillations during the Eemian Interglacial - preliminary results of multi-proxy researches of palaeolake at Solniki. NE Poland. Polish Geological Institute Special Papers, 16: 53-57. 
Kupryjanowicz, M., Granoszewski, W., Nalepka, D., Pidek, I.A., Walanus, A., Balwierz, Z., Fiłoc M., Kołaczek, P., Majecka, M., Malkiewicz, M., Nita, M., Noryśkiewicz, B., Winter, H., 2016. Instability of the environment at the end of the Eemian Interglacial as illustrated by the isopollen maps for Poland. Geological Quarterly, 60 (1): 225-237.

Kupryjanowicz, M., Fiłoc, M., Kwiatkowski, W., 2018. Was there an abrupt cold climatic event in the middle Eemian? Pollen record from a palaeolake at the Hieronimowo site, NE Poland. Quaternary International, 467: 96-106.

Kupryjanowicz, M., Fiłoc, M., Drzymulska, D., Poska, A., Suchora, M., Żarski, M., Mroczek, P., 2021. Environmental changes of the stadial/interstadial type during the Late Saalian (MIS-6) - multi-proxy record at the Wola Starogrodzka site, central Poland. Palaeogeography, Palaeoclimatology, Palaeoecology, 572, 110420.

Lauterbach, S., Brauer, A., Litt, T., Schettler, G., 2012. Re-evaluation of the Bispingen palaeolake record - a revised chronology for the Eemian in Northern Germany. EGU Geophysical Research Abstracts: 8613.

Mamakowa, K., 1989. Late Middle Polish Glaciation, Eemian and Early Vistulian vegetation at Imbramowice near Wrocław and the pollen stratigraphy of this part of the Pleistocene in Poland. Acta Palaeobotanica, 29: 11-176.

Marks, L., Gałązka, D., Woronko, B., 2016. Climate, environment and stratigraphy of the last Pleistocene glacial stage in Poland. Quaternary International, 420: 259-271.

Matuszkiewicz, W., 2001. Przewodnik do oznaczania zbiorowisk roślinnych Polski (in Polish). Wydawnictwo Naukowe PWN, Warszawa.

Mauquoy, D., van Geel, B., 2007. Plant macrofossil methods and studies: Mire and Peat Macros. Encyclopedia of Quaternary Science: 2315-2336.

Mirosław-Grabowska, J., Niska, M., 2005. Isotopic and Cladocera records of climate changes of Early Eemian at Besiekierz (Central Poland). Geological Quarterly, 49 (1): 67-74.

Mirosław-Grabowska, J., Niska, M., 2007. Isotope and Cladocera data and interpretation from the Eemian optimum and postoptimum deposits, Kaliska palaeolake (Central Poland). Quaternary International, 175: 155-167.

Mirosław-Grabowska, J., Niska, M., Sienkiewicz, E., 2009. Evolution of the palaeolake at Ruszkówek (Central Poland) during the Eemian Interglacial based on isotope, cladoceran and diatom data. Journal of Paleolimnology, 42: 467-481.

Mirosław-Grabowska, J., Niska, M., Roman, M., 2018. Long (MIS $5 e-3$ ) environmental history of a paleolake in central Poland recorded in the succession from Kubłowo. Quaternary International, 467: 26-42.

Nalepka, D., Walanus, A., 2003. Data processing in pollen analysis. Acta Palaeobotanica, 43: 125-134.

Niklewski, J., 1968. The Eemian Interglacial at Główczyn near Wyszogród (Central Poland) (in Polish with English summary). Monographie Botanicae, 27: 125-192.

North GRIP members, 2004. High-resolution record of northern hemisphere climate extending into the last interglacial period. Nature, 431: 147-151.
Pidek, I.A., Svitavska-Svobodova, H., Van der Knaap, W.O., Magyari, E., 2013. Pollen percentage thresholds of Abies alba based on 13-year annual records of pollen deposition in modified Tauber traps: perspectives of application to fossil situations. Review of Palaeobotany and Palynology, 195: 26-36.

Pidek, I.A., Hrynowiecka, A., Zalat, A.A., Żarski, M., 2021. A high-resolution pollen and diatom record of mid- to late-Eemian at Kozłów (Central Poland) reveals no drastic climate changes in the hornbeam phase of this interglacial. Quaternary International, 583: 14-30.

Raniecka-Bobrowska, J., 1954. Pollen analysis of Quaternary profiles of Wola and Żoliborz in Warsaw (in Polish with English summary). Biuletyn Instytutu Geologicznego, 69: 107-140.

Roman, M., 2016. Eemian lakeland: remarks on origin and decline of the post-glacial lakesin Central Poland (in Polish with English summary). Acta Geographica Lodziensia, 105: 11-25.

Roman, M., Balwierz, Z., 2010. Eemian and Vistulian pollen sequence at Kubłowo (Central Poland): implications for the limit of the Last Glacial Maximum. Geological Quarterly, 54 (1): 55-68.

Roman, M., Mirosław-Grabowska, J., Niska, M., 2021. The Eemian Lakeland of the central Polish Plain: environmental changes and palaeogeography. Palaeogeography, Palaeoclimatology, Palaeoecology, 561: 110087.

Sobolewska, M., 1961. Eemian interglacial flora from Góra Kalwaria (Central Poland) (in Polish with English summary). Biuletyn Instytutu Geologicznego, 169: 73-90.

Solon, J., Borzyszkowski, J., Bidłasik, M., Richling, A., Badora, K., Balon, J., Brzezińska-Wójcik, T., Chabudziński, Ł., Dobrowolski, R., Grzegorczyk, I., Jodłowski, M., Kistowski, M., Kot, R., Krąż, P., Lechnio, J., Macias, A., Majchrowska, A., Malinowska, E., Migoń, P., Myga-Piątek, U., Nita, J., Papińska E., Rodzik, J., Strzyż, M., Terpiłowski, S., Ziaja, W., 2018. Physico-geographical mesoregions of Poland: verification and adjustment of boundaries on the basis of contemporary spatial data. Geographia Polonica, 91: 143-170.

Wachecka-Kotkowska, L., Krzyszkowski, D., Malkiewicz, M., Mirosław-Grabowska, J., Niska, M., Krzymińska, J., Myśkow, E., Raczyk, J., Wieczorek, D., Stoiński, Rzodkiewicz, M., 2018. An attempt to reconstruct the late Saalian to Plenivistulian (MIS6-MIS3) natural lake environment from the "Parchliny 2014" section, central Poland. Quaternary International, 467: 5-25.

Zalat, A.A., Bober, A., Pidek, I.A., Żarski, M., 2021. Environmental and climate change during the Late Saalian-Eemian Interglacial at the Struga site (Central Poland): a diatom record against the background of palynostratigraphy. Review of Palaeobotany and Palynology, 288, 104386.

Żarski, M., 1989. A new locality of Eemian Interglacial deposits near Dęblin (in Polish with English summary). Geological Quarterly, 33 (2): 269-274.

Żarski, M., 2020. Szczegółowa mapa geologiczna Polski w skali 1:50 000 arkusz Garwolin (566) (in Polish). PIG-PIB, Warszawa.

Żarski, M., Nita, M., Winter, H., 2005. New interglacial sites in the region of the Wilga and Okrzejka river valleys at the Żelechów Upland (SE Poland) (in Polish with English summary). Przegląd Geologiczny, 53: 137-144. 